\title{
Morphological diversity and heritability of nine local sorghum (Sorghum bicolor) genotypes in East Java, Indonesia
}

\author{
MAFTUCHAH $^{1,3, \vartheta}$, LIA FEBRIANA ${ }^{1}$, SULISTYAWATI ${ }^{2}$, HELVI ARDANA RESWARI ${ }^{1}$, ERFAN DANI SEPTIA ${ }^{1,3}$ \\ ${ }^{1}$ Faculty of Agriculture and Animal Science, Universitas Muhammadiyah Malang. Jl. Raya Tlogomas 246, Malang 65144, East Java, Indonesia \\ Tel./fax.: +62-341-464318 (145), •email: maftuchah@umm.ac.id \\ ${ }^{2}$ Faculty of Agriculture, Universitas Merdeka Pasuruan. Jl. Ir. H. Juanda No. 68, Pasuruan City 67129, East Java, Indonesia \\ ${ }^{3}$ Center of Biotechnology Development, Universitas Muhammadiyah Malang. Jl. Tlogomas No. 246, Malang 65144, East Java, Indonesia.
}

Manuscript received: 25 September 2020. Revision accepted: 16 February 2021.

\begin{abstract}
Maftuchah, Febriana L, Sulistyawati, Reswari HA, Septia ED. 2021. Morphological diversity and heritability of nine local sorghum (Sorghum bicolor) genotypes in East Java, Indonesia. Biodiversitas 22: 1310-1316. Sorghum (Sorghum bicolor L. Moench) is an essential food crop after wheat, rice, maize, and barley. It has wide adaptability to various environmental conditions, including can be grown on marginal lands, so that it is potential to be developed as cheap source of carbohydrates. The present study obtain information about the morphological diversity and heritability values of local sorghum genotypes that occurred in East Java Province, Indonesia. The research was conducted in Purutrejo village, Pasuruan city using nine local genotypes, namely Jombang (SG-JBG), Tuban (SG-TBN), Pasuruan (GB-PSR), Lamongan 1 (SG-LMG 1), Lamongan 2 (SG-LMG 2), Sampang 1 (SG-SPG 1), Sampang 2 (SG-SPG 2), Tulungagung 1 (SG-TLG 1) and Tulungagung 2 (SG-TLG 2). The results showed that the genotype of SG-SPG 2 produced the longest panicles, while the SG-LMG 2 had the highest seed dry weight per panicle and highest number of seeds per panicle (117.34 gram/panicle dry weight and 4581.80 seeds/panicle). The genotype of SG-TLG 2 produced the largest weight of seeds, either in fresh seed (41.43 g/1000 seeds) or dry seed (31.96 g/1000 seeds). Of the nine genotypes tested, the flowering ages ranged from 42 to 53 days after planting, and the harvest ages ranged from 70 to 91 days after planting with the fastest harvest age was achieved by SG-TLG 2 The entire value of the phenotype variety on each variable was more significant than the value of the genotype range. Heritability test results show that all experimental parameters exceed 0.5 so that it is categorized as high heritability. In general, the SG-TLG 2 genotype had the most chance to be developed, because it produced the highest seed weight, both fresh seeds (41.43 g/1000 seeds) and dry seeds (31.96 g/1000 seeds). Besides, the SG-TLG shows the fastest harvest age (70 days after planting).
\end{abstract}

Keywords: Diversity, heritability, landrace, Sorghum bicolor

\section{INTRODUCTION}

Human population growth globally has increased the need for various agricultural commodities, especially cereals and pulses. Among the cereals, sorghum (Sorghum bicolor L) is one of the world's essential crops as the primary source of carbohydrates after wheat, rice, corn, and barley. Sorghum could be developed as an alternative to substitute and/or to complement local food consumption besides rice to enhance food diversification. In addition to human food sources, sorghum has also the potential as animal feed and raw materials for various industries.

Sorghum is an annual crop that is easy to cultivate, but its production is still lower than that of rice, maize, and other cereal crops. The rice production level increased by around $2.33 \%$, while maize increased by $3.91 \%$ from 2017 to 2018. However, sorghum production data is still not available, so that sorghum production is still small and not well recorded (MoA 2020). Sorghum has wide environmental adaptability and can be developed in areas with less adaptive environmental conditions to climate change (Mundia et al. 2019). As such, sorghum has more potential to be developed as an alternative crop on marginal lands compared to rice to increase local food supplies (Sulistyawati et al. 2019a). Besides, current research indicated that several local genotypes of sorghum, which contain high carbohydrates and protein, could be used for various food preparations (Sulistyawati et al. 2019b). Any efforts in sorghum improvement would help government initiatives in reducing the burden of rice production and wheat import (Sulistyawati and Saliem 2013).

Genetic characterization of germplasm lines aims to identify important traits that have economic value or specific characteristics to be targeted and retained. The characters could be morphological (e.g., Plant height, number of leaves, stem diameter, panicle length, leaf width, leaf length, etc.) and agronomic (e.g., days of flower, fresh weight 1000 seeds, days of maturity time, dry weight 1000 seeds, total seed dry weight per panicle, etc.). The processes of characterization and evaluation have essential meanings and roles to obtain the genetic lines that have excellent traits (Kusumawati et al. 2013). In the context of sorghum, the differences in genotype could be recognized more clearly in the generative phase than in the vegetative phase (Elvira et al. 2015).

The diversity in crop varieties and accessions will help plant breeding activities, especially in providing plant breeding materials (Rifa'i et al. 2015). Genetic diversity facilitates the selection process in field crops including sorghum. If the genetic variance is high, the heritability 
value would be high. Thus, the variable could be used as a selection criterion (Setiawan et al. 2019). Heritability value could be interpreted as the proportion between genetic variance and phenotypic variance (Falconer and Mackay 1996). The heritability value of a character do not necessarily indicate that the character inherited is affected by genetic factors or environmental conditions (Maftuchah et al. 2015).

Similarly, information on morphological diversity and heritability values in sorghum would help breeders to obtain local sorghum genotypes with preferred characteristics suitable for particular purposes, for example as an alternative food source for human consumption, animal feeding, or raw material of fuel production. The present study aimed to obtain information about the morphological diversity and heritability values of local sorghum genotypes that occurred in East Java Province, Indonesia. We expected the results of this study could serve as baseline information for future research and development of sorghum cultivation, especially in East Java.

\section{MATERIALS AND METHODS}

\section{Plant materials}

The research was conducted in Purutrejo Village, Purworejo Sub-district, Pasuruan City, East Java Province, Indonesia. Plant materials used in this study were nine genotypes of local sorghum plants derived from various regions in East Java, i.e., Jombang (SG-JBG), Tuban (SGTBN), Pasuruan (GB-PSR), Lamongan 1 (SG-LMG 1), Lamongan 2 (SG-LMG 2), Sampang 1 (SG-SPG 1), Sampang 2 (SG-SPG 2), Tulungagung 1 (SG-TLG 1), and Tulungagung 2 (SG-TLG 2).

\section{Experimental design}

The experiment was conducted as randomized block design with three replications. The design consisted of one factor (i.e. nine genotypes of local sorghum) so that there was 27 experimental units in total. The planting of sorghum was carried out by sowing sorghum seeds on a tray used a planting medium containing soil and compost. Seedlings were then planted in the field after ten days of sowing with a planting distance of $75 \mathrm{~cm} \mathrm{x} 15 \mathrm{~cm}$ at plots measuring $3 \times$ $2.5 \mathrm{~m}$. Thus, each plot consisted of 21 sorghum plants. The fertilizers used were organic fertilizers and chemical fertilizers (SP 36, Urea, and KCL). Manure is an essential fertilizer given at the same time when conducted tilling. Meanwhile, chemical fertilizers were applied to the planting hole when the plants were 2 weeks after planting (WAP) and 4 WAP. The flow chart of this research activity's implementation is in Figure 1.

\section{Data collection and analysis}

The variables observed were plant height, number of leaves, stem diameter, panicle length, total dry weight of grains per panicle, number of grains per panicle, fresh weight of 1000 grains, dry weight of 1000 grains, leaf length, leaf width, plant height at harvest, tillers, age, and harvest of flowering and harvest age. Data analysis was performed using variance analysis and continued with the 5\% LSD test, analysis of variance and heritability testing. Analysis of genotype variety, phenotype variety and environmental variance using the formulas $(\boldsymbol{\sigma} 2 \mathrm{e}=\mathrm{M} 1)$, $(\boldsymbol{\sigma} 2 \mathrm{~g}=(\mathrm{M} 2-\mathrm{M} 1) / \mathrm{r})$ and $(\boldsymbol{\sigma} 2 \mathrm{p}=\boldsymbol{\sigma} 2 \mathrm{e}+\boldsymbol{\sigma} 2 \mathrm{~g})$. The M1 and M2 are based on Table 1 . The diversity criteria used to follow Pinaria et al. (1995) provisions, namely broad variability if the diversity value is $>$ twice the standard deviation of genetic variance and narrow variability if the variability is <twice the standard deviation of genetic variance. The formula used in estimating heritability is $\mathrm{H}=$ $\boldsymbol{\sigma} 2 \mathrm{~g} / \boldsymbol{\sigma} 2 \mathrm{p}$. and classified according to Mac Whirter (1979), namely low heritability: $<0.20$, medium heritability: 0.20 0.50 , high heritability: $0.50<\mathrm{H} \leq 1$.

Table 1. Analysis of variance

\begin{tabular}{lccc}
\hline $\begin{array}{c}\text { Sources of } \\
\text { diversity (SK) }\end{array}$ & $\begin{array}{c}\text { Degrees of } \\
\text { free (DB) }\end{array}$ & $\begin{array}{c}\text { Sum of } \\
\text { squares (JK) }\end{array}$ & $\begin{array}{c}\text { Middle- } \\
\text { value square } \\
\text { (KT) }\end{array}$ \\
\hline Group & $\mathrm{r}-1$ & $\mathrm{JKK}$ & \\
Genotype & $\mathrm{g}-1$ & $\mathrm{JKG}$ & $\mathrm{M} 2$ \\
Error & $(\mathrm{r}-1)(\mathrm{g}-1)$ & $\mathrm{JKG}$ & $\mathrm{M} 1$ \\
\hline
\end{tabular}

Figure 1. Flowchart of research implementation 


\section{RESULTS AND DISCUSSION}

\section{Morphological characters}

Genotypic factors showed significant differences in plant height and number of leaves at 21, 28, and 35 days after planting. Table 2 shows the average plant height and number of leaves of the nine local sorghum genotypes in East Java at various observation ages. Our results indicate that the genotype of SG-TLG 2 had the highest plant height with $63.97 \mathrm{~cm}$, followed by SG-JBG and SG-TLG 1 with 63.30 and $62.04 \mathrm{~cm}$, respectively. On the other hand, the highest average number of leaves was shown by the genotype of SG-JBG with 8.53 strands, followed by SG-TLG 1 and SG-LMG 1 with 8.40 and 8.33 strands, respectively.

Plant's appearance is influenced by one genetic factor (Panjaitan et al. 2015). Plant height is one of the growth parameters that is often used to determine environmental or genetic influences. Leaves are the primary organ for photosynthesis. The influence of the environment results in the genotype being able to display its character. The existence of inappropriate environmental influences results in the appearance of genetic traits that is not optimal.

Table 2. Plant height $(\mathrm{cm})$ and number of leaves (strands) of several East Java local sorghum (Sorghum bicolor) genotypes at various observation ages

\begin{tabular}{|c|c|c|c|c|c|c|c|c|c|c|c|c|c|c|c|c|}
\hline \multirow{3}{*}{$\begin{array}{l}\text { Genotype } \\
\text { SG-JBG }\end{array}$} & \multicolumn{8}{|c|}{ Plant height (cm) } & \multicolumn{8}{|c|}{ Number of leaves (strands) } \\
\hline & \multicolumn{2}{|c|}{14 DAP } & \multicolumn{2}{|c|}{21 DAP } & \multicolumn{2}{|c|}{28 DAP } & \multicolumn{2}{|c|}{35 DAP } & \multicolumn{2}{|c|}{14 DAP } & \multicolumn{2}{|c|}{21 DAP } & \multicolumn{2}{|c|}{ 28 DAP } & \multicolumn{2}{|c|}{35 DAP } \\
\hline & 8.56 & $\mathrm{a}$ & 14.99 & $\mathrm{~b}$ & 24.16 & cd & 63.30 & $\mathrm{e}$ & 4.80 & $\mathrm{~d}$ & 6.80 & d & 7.93 & c & 8.53 & $\mathrm{e}$ \\
\hline SG-TBN & 7.55 & a & 13.71 & $a b$ & 22.10 & $a b$ & 48.37 & bcd & 4.47 & $\mathrm{bc}$ & 6.47 & $\mathrm{~cd}$ & 7.80 & bc & 8.13 & de \\
\hline SG-PSR & 8.31 & a & 15.42 & $\mathrm{~b}$ & 22.88 & $a b c$ & 55.55 & cde & 3.93 & $\mathrm{~b}$ & 5.80 & $\mathrm{~cd}$ & 7.07 & bc & 7.20 & $\mathrm{~cd}$ \\
\hline SG-LMG 1 & 7.96 & $\mathrm{a}$ & 13.30 & $a b$ & 22.65 & $a b c$ & 42.14 & $a b c$ & 4.27 & $\mathrm{bc}$ & 5.87 & $\mathrm{~cd}$ & 7.87 & $\mathrm{c}$ & 8.33 & $\mathrm{e}$ \\
\hline SG-LMG 2 & 6.97 & $\mathrm{a}$ & 13.89 & $a b$ & 20.43 & $a b$ & 34.80 & $a b$ & 4.07 & $\mathrm{bc}$ & 5.80 & $\mathrm{~cd}$ & 7.27 & $\mathrm{bc}$ & 8.20 & de \\
\hline SG-SPG 1 & 7.13 & $\mathrm{a}$ & 11.03 & $\mathrm{a}$ & 17.27 & $\mathrm{a}$ & 29.55 & $\mathrm{a}$ & 2.53 & $\mathrm{a}$ & 2.87 & $\mathrm{a}$ & 4.67 & $\mathrm{a}$ & 5.13 & $\mathrm{a}$ \\
\hline SG-SPG 2 & 6.84 & $\mathrm{a}$ & 15.94 & $\mathrm{~b}$ & 29.02 & $\mathrm{~cd}$ & 46.60 & bc & 3.87 & b & 4.53 & $\mathrm{~b}$ & 5.33 & $\mathrm{a}$ & 5.67 & $a b$ \\
\hline SG-TLG 1 & 9.21 & $\mathrm{a}$ & 15.91 & $\mathrm{~b}$ & 26.91 & $\mathrm{bc}$ & 62.04 & de & 4.00 & $\mathrm{bc}$ & 6.33 & $\mathrm{~cd}$ & 7.47 & bc & 8.40 & $\mathrm{e}$ \\
\hline SG-TLG 2 & 8.43 & $\mathrm{a}$ & 15.77 & $\mathrm{~b}$ & 33.87 & $\mathrm{~d}$ & 63.97 & $\mathrm{e}$ & 4.00 & $\mathrm{bc}$ & 5.60 & $\mathrm{bc}$ & 6.73 & $\mathrm{bc}$ & 6.73 & $\mathrm{~cd}$ \\
\hline
\end{tabular}

Note: The numbers followed by the same letter in the same column show no significant difference in the 5\% LSD test.
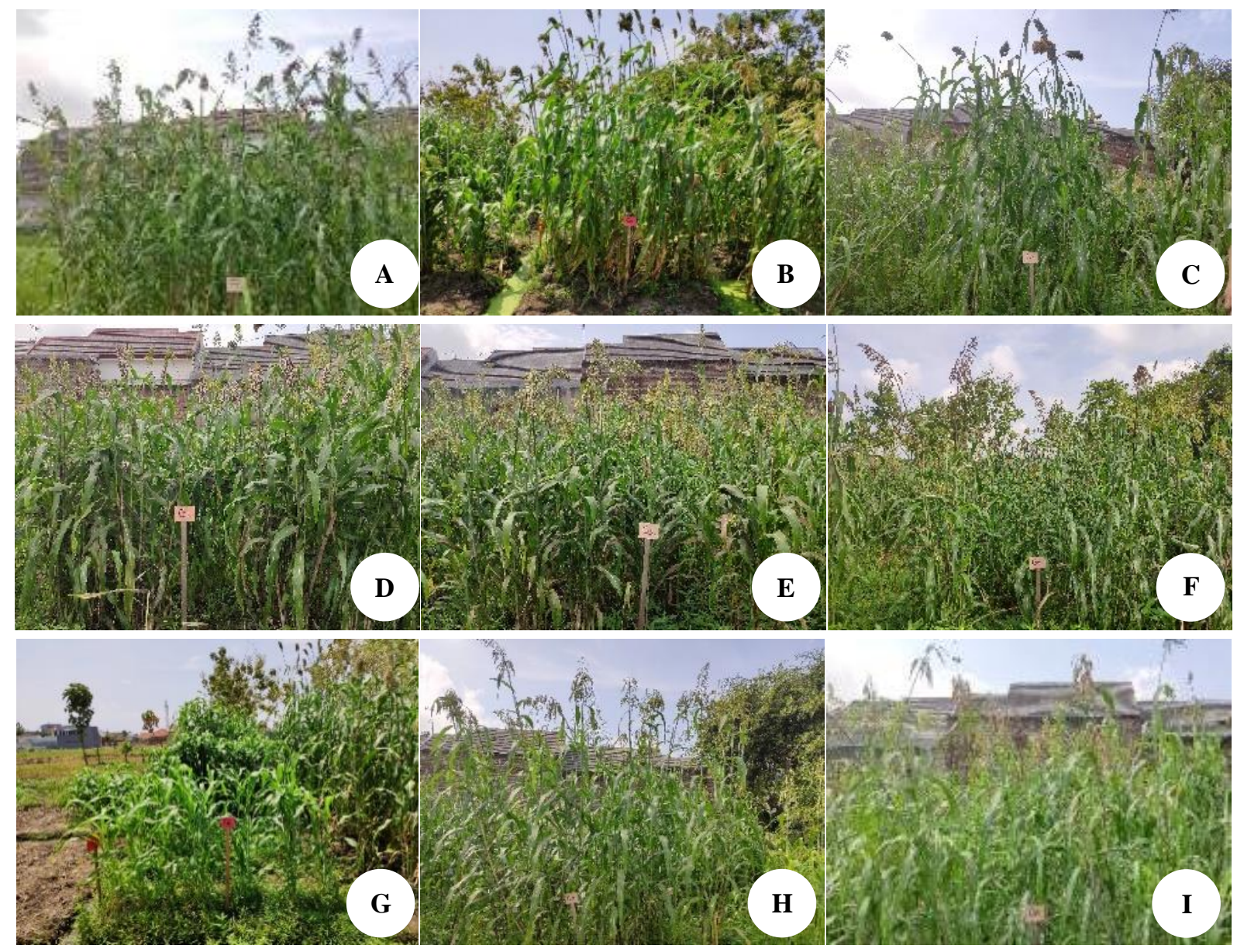

Figure 2. Plant morphology in the experimental fields: A. SG-JBG, B. SG-TBN, C. GB-PSR, D. SG-LMG 1, E. SG-LMG 2, F. SGSPG 1, G. SG-SPG 2, H. SG-TLG 1, I. SG-TLG 2 
Table 3 shows the average stem diameter at 28 DAP and 35 DAP, leaf length and width, the average plant height at harvest and the number of tillers. The biggest stem diameter was obtained by the genotypes of SG-LMG 2 and SG-TLG 1 with $1.83 \mathrm{~cm}$ and $1.56 \mathrm{~cm}$ followed by SG-TBN with $1.51 \mathrm{~cm}$. The genotype of SG-LMG 1 had the longest leaf with $82.14 \mathrm{~cm}$ followed by SG-TLG 1 and SG-TBN with $80.11 \mathrm{~cm}$ and $79.15 \mathrm{~cm}$ respectively, while the genotype with the biggest leaf width was SG-LMG 1 with $8.84 \mathrm{~cm}$, followed by SG-LMG 2 and SG-TLG 1 with $8.24 \mathrm{~cm}$ and $7.84 \mathrm{~cm}$, respectively. When harvested, SG-TLG 1 had the highest height with $274.23 \mathrm{~cm}$, followed by SG-TBN and SG-JBG with $262.33 \mathrm{~cm}$ and $255.72 \mathrm{~cm}$ respectively, while the genotype with the largest number of tillers was SGTLG 2 with 4.20, followed by SG-TLG 1 and SG-PSR with 3.33 and 2.27, respectively. Nonetheless, the highest number of tillers which was produced by genotype SGTLG did not differ significantly from SG-TLG 2.

The varying observation results indicate that each genotype has different characteristics. Siswanto (2015) states that the genetic characteristics of varieties, the environment in which they are grown, and the cultivation treatment will affect sorghum's yield potential. Genetic and environmental factors determine the number of tillers produced.

\section{Yield contributing traits}

Observed parameters related to yield contributing traits include average panicle length, total seed dry weight per panicle, number of seeds per panicle, fresh weight, and dry weight 1000 seeds. The results of such parameters for each sorghum genotype studied here are presented in Table 4. The genotype of SG-SPG 2 had the longest panicle size with $47.75 \mathrm{~cm}$, followed by SG-TLG 2 and SG-TLG 1 with $41.73 \mathrm{~cm}$ and $41.29 \mathrm{~cm}$, respectively. The genotype of SGLMG 2 produced the largest seed dry weight per panicle $(117.34 \mathrm{~g})$, followed by SG-JBG and SB-TLG 2 with, $88.87 \mathrm{~g}$ and $86.69 \mathrm{~g}$ respectively. while the genotype with the largest number of seeds per panicle was SG-LMG 2 with 4581.80, followed SG-LMG 1 and SG-TBN with 3563.90 and 3125.70 respectively. The genotype of SGTLG 2 had the highest fresh weight 1000 seed with 41.43 $\mathrm{g}$, followed by SG-TLG 1 and SG-JBG with $41.04 \mathrm{~g}$ and $37.86 \mathrm{~g}$, respectively. While the highest dry weight 1000 seed was SG-TLG 2 with $31.96 \mathrm{~g}$, followed SG-TLG 1 and SG-PSR with $31.55 \mathrm{~g}$ and $30.06 \mathrm{~g}$, respectively.

Long panicles of plants are formed in the primordia phase. The difference in panicle length is due to different genotypes and inherited traits. Each genetic factor and the adaptability of each variety is different so that it affects the length of sorghum panicles (Sirappa and Waas 2009). Total dry weight is one measure to study further plant growth (Ferdian et al. 2015). The total dry weight per panicle is one of the criteria for the production of sorghum. Genetic differences will result in a different panicle shape or weight of the seed unit so that each genotype has a different dry weight. Plants require sufficient nutrient content for seed formation. Genotypic differences result in different shapes and weights of seeds.

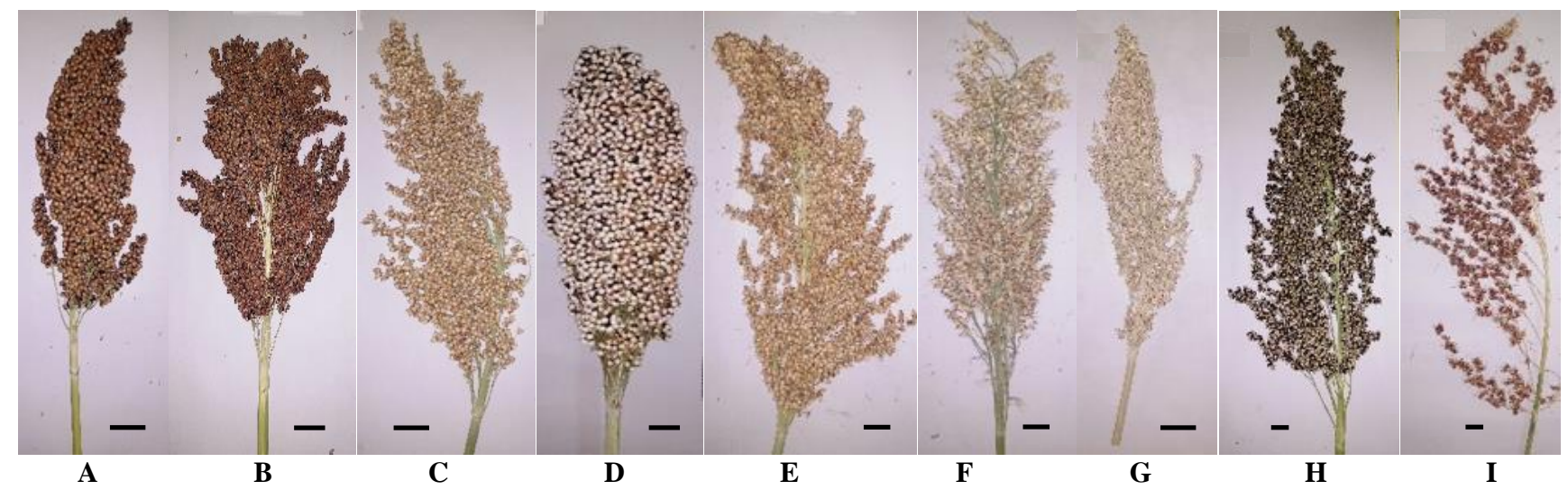

Figure 3. Seed morphology of several genotypes: A. SG-JBG, B. SG-TBN, C. SG-PSR, D. SG-LMG 1, E. SG-LMG 2, F. SG-SPG 1, G. SG-SPG 2, H. SG-TLG 1, I. SG-TLG 2. Bar $=2 \mathrm{~cm}$

Table 3. Average stem diameter, length, the width of leaves, the value of plant height at harvest, and number of tillers of several East Java local sorghum (Sorghum bicolor (L.) genotypes

\begin{tabular}{|c|c|c|c|c|c|c|c|c|c|c|c|c|}
\hline \multirow{2}{*}{ Genotype } & \multicolumn{4}{|c|}{ Stem diameter $(\mathbf{c m})$} & \multirow{2}{*}{\multicolumn{2}{|c|}{$\begin{array}{l}\text { Leaf length } \\
\text { (cm) }\end{array}$}} & \multirow{2}{*}{\multicolumn{2}{|c|}{$\begin{array}{l}\text { Leaf width } \\
\text { (cm) }\end{array}$}} & \multirow{2}{*}{\multicolumn{2}{|c|}{$\begin{array}{l}\text { Plant height at } \\
\text { harvest }(\mathrm{cm})\end{array}$}} & \multirow{2}{*}{\multicolumn{2}{|c|}{$\begin{array}{c}\text { Number of } \\
\text { tillers }\end{array}$}} \\
\hline & \multicolumn{2}{|c|}{28 DAP } & \multicolumn{2}{|c|}{35 DAP } & & & & & & & & \\
\hline SG-JBG & 1.27 & $\mathrm{bc}$ & 1.47 & bcd & 77.27 & $\mathrm{~d}$ & 7.70 & $\mathrm{~d}$ & 255.72 & $\mathrm{~d}$ & 2.07 & $\mathrm{c}$ \\
\hline SG-TBN & 1.29 & $\mathrm{bc}$ & 1.51 & $\mathrm{~cd}$ & 79.15 & $\mathrm{~d}$ & 7.82 & de & 262.33 & $\mathrm{~d}$ & 213 & $a b$ \\
\hline SG-PSR & 1.14 & $\mathrm{abc}$ & 1.19 & $a b$ & 78.40 & d & 6.75 & c & 202.40 & $\mathrm{c}$ & 2,27 & $a b$ \\
\hline SG-LMG 1 & 1.26 & $a b c$ & 1.46 & bcd & 82.14 & d & 8.84 & e & 139.47 & a & 1.33 & a \\
\hline SG-LMG 2 & 1.37 & $\mathrm{c}$ & 1.83 & $\mathrm{e}$ & 76.01 & $\mathrm{~cd}$ & 8.24 & de & 167.50 & $\mathrm{~b}$ & 1.87 & $\mathrm{a}$ \\
\hline SG-SPG 1 & 1.19 & $a b c$ & 1.24 & $a b c$ & 69.96 & $\mathrm{bc}$ & 5.69 & $\mathrm{~b}$ & 191.67 & $\mathrm{c}$ & 2.07 & $a b$ \\
\hline SG-SPG 2 & 0.93 & $\mathrm{a}$ & 1.05 & $\mathrm{a}$ & 49.29 & $\mathrm{a}$ & 4.56 & $\mathrm{a}$ & 136.15 & $\mathrm{a}$ & 1.80 & $\mathrm{a}$ \\
\hline SG-TLG 1 & 1.37 & $\mathrm{c}$ & 1.56 & de & 80.11 & d & 7.84 & de & 274.23 & d & 3.33 & $\mathrm{bc}$ \\
\hline SG-TLG 2 & 1.02 & $a b$ & 1.03 & $\mathrm{a}$ & 68.33 & $\mathrm{bc}$ & 4.79 & $a b$ & 214.05 & $\mathrm{c}$ & 4.20 & $\mathrm{c}$ \\
\hline
\end{tabular}

Note: The numbers followed by the same letter in the same column show no significant difference in the 5\% LDS test 
Table 4. The average length of panicle, total dry weight of seeds per panicle number of seeds, fresh and dry weight of 1000 seeds per panicle of several East Java local sorghum (Sorghum bicolor) genotypes

\begin{tabular}{|c|c|c|c|c|c|c|c|c|c|c|}
\hline \multirow{2}{*}{$\begin{array}{l}\text { Genotype } \\
\text { SG-JBG }\end{array}$} & \multicolumn{2}{|c|}{$\begin{array}{c}\text { Panicle length } \\
(\mathrm{cm})\end{array}$} & \multicolumn{2}{|c|}{$\begin{array}{l}\text { Total seed dry weight } \\
\text { per panicle (g/panicle) }\end{array}$} & \multicolumn{2}{|c|}{$\begin{array}{l}\text { Number of seeds } \\
\text { per panicle }\end{array}$} & \multicolumn{2}{|c|}{$\begin{array}{l}\text { Fresh weight } \\
1000 \text { seeds }(g)\end{array}$} & \multicolumn{2}{|c|}{$\begin{array}{c}\text { Dry weight } \\
1000 \text { seeds }(g)\end{array}$} \\
\hline & 23.92 & $\mathrm{a}$ & 88.87 & c & 3081.80 & $\mathrm{de}$ & 37.86 & cde & 28.87 & $\mathrm{~cd}$ \\
\hline SG-TBN & 26.13 & $\mathrm{a}$ & 82.94 & $\mathrm{bc}$ & 3125.70 & de & 34.61 & $\mathrm{bc}$ & 26.50 & $\mathrm{bc}$ \\
\hline SG-PSR & 34.69 & $\mathrm{~b}$ & 68.68 & b & 2293.90 & $\mathrm{bc}$ & 37.25 & $\mathrm{~cd}$ & 30.06 & de \\
\hline SG-LMG 1 & 25.50 & $\mathrm{a}$ & 86.68 & $\mathrm{bc}$ & 3563.90 & e & 34.07 & bc & 24.66 & $a b$ \\
\hline SG-LMG 2 & 38.53 & $\mathrm{bc}$ & 117.34 & d & 4581.80 & $\mathrm{f}$ & 32.73 & $\mathrm{~b}$ & 25.87 & $a b$ \\
\hline SG-SPG 1 & 35.83 & $\mathrm{~b}$ & 44.23 & $\mathrm{a}$ & 1962.10 & $a b$ & 26.45 & a & 23.22 & a \\
\hline SG-SPG 2 & 47.75 & d & 48.70 & $\mathrm{a}$ & 1840.80 & $a b$ & 32.65 & $\mathrm{~b}$ & 26.51 & $\mathrm{bc}$ \\
\hline SG-TLG 1 & 41.29 & $\mathrm{c}$ & 86.69 & $\mathrm{bc}$ & 2746.60 & $\mathrm{~cd}$ & 41.04 & de & 31.55 & de \\
\hline SG-TLG 2 & 41.73 & $\mathrm{c}$ & 45.72 & $\mathrm{a}$ & 1426.80 & a & 41.43 & $\mathrm{e}$ & 31.96 & $\mathrm{e}$ \\
\hline
\end{tabular}

Note: The numbers followed by the same letter in the same column show no significant difference in the 5\% LDS test

Table 5 shows that the flowering ages ranged from 42 to 53 days after planting. Meanwhile, the harvest age ranged from 70 to 91 days after planting with the fastest harvesting age was on genotype SG-TLG 2 (70 days after planting), followed by SG-PSR, SG-LMG 1, and SG-TLG 1 with 77 days after planting. The existence of the suitability of environmental conditions can stimulate the flowering and harvesting age faster. Besides, the nutrients absorbed by plants are used as a source of energy in plant growth (Setiyagama 2017).

\section{Genetic variability and heritability}

The analysis of environment, genotype, and phenotype variability is shown in Table 6 . These data indicate the criteria for broad genotype and phenotype variance. All values for the phenotype variety on each variable were more significant than the values for genotype variance. The indication of this is the influence of the genotype and the environment (Kotal et al. 2010). Genotype diversity is a measure of genetic variation caused by the components of the genotype. In contrast, phenotype diversity is a variation of characters regulated by genotype factors and the growing environment, and the two's interaction.

The wide variety of genotypes in the nine local sorghum genotypes in East Java indicates inequalities in genetic characters between genotypes. Dominant genotype variety is the main cause of the inequality of characters among plant relatives. High genetic diversity indicates a high potential for use in the improvement of plant traits. Genetic facts are inferred from phenotypic observations, which are the results of genotype interactions and the environment. The variability available in breeding material is the prime requirement for improving and selecting elite genotypes (Seetharam and Ganesamurthy 2013).

Heritability value analysis shows that all tested parameters exceed 0.5 for each observed variable so that it is categorized as high heritability. Chaudhary (2001) stated that the high coefficient of phenotype variety compared to the coefficient of genotype variance indicates a good effect on all genotypes' environment. The wide diversity of phenotypes comes from a wide diversity of genotypes, so that the requirement for the selection process to take place in the genotype selection process is wide genetic diversity. (Rahajeng and Rahayuningtyas 2015).

In a broad sense, the heritability prediction value is the ratio between the total genetic variance and the phenotype variety, which shows the large proportion of genetic factors in a plant character's phenotype. The estimated high heritability means that plant genetic factors that affect plant phenotypes are very large compared to environmental factors (Ardiyanti et al. 2019). The phenotype variety analysis showed that the phenotype diversity in all observed genotypes was also high (Table 7). In general, high genotype diversity will be followed by high phenotype diversity. The diversity that will be inherited can be measured using the heritability parameter. It is a broad sense, a comparison between the magnitude variety of genotypes and a character's phenotypes.

Table 5. Flowering age, flowering to harvest, and harvesting age of several East Java local sorghum (Sorghum bicolor) genotypes

\begin{tabular}{lccc}
\hline \multicolumn{1}{c}{ Genotype } & $\begin{array}{c}\text { Days to } \\
\text { flower } \\
\text { (DAP) }\end{array}$ & $\begin{array}{c}\text { Flowering to } \\
\text { harvest } \\
\text { (days) }\end{array}$ & $\begin{array}{c}\text { Days to } \\
\text { maturity } \\
\text { (DAP) }\end{array}$ \\
\hline SG-JBG & 53 & 38 & 91 \\
SG-TBN & 53 & 33 & 86 \\
SG-PSR & 49 & 28 & 77 \\
SG-LMG 1 & 49 & 28 & 77 \\
SG-LMG 2 & 51 & 35 & 86 \\
SG-SPG 1 & 42 & 44 & 86 \\
SG-SPG 2 & 42 & 49 & 91 \\
SG-TLG 1 & 53 & 24 & 77 \\
SG-TLG 2 & 38 & 32 & 70 \\
\hline
\end{tabular}

Note: Days to maturity is the sum of days after planting to flower and days of flowering to harvest 
Table 6. Analysis of environmental variety, genotype, and phenotype of several East Java local sorghum (Sorghum bicolor) genotypes

\begin{tabular}{|c|c|c|c|c|c|c|c|}
\hline Traits & $\sigma^{2} \mathrm{e}$ & $\sigma^{2} g$ & $2 \sigma \mathrm{g}$ & Criteria & $\sigma^{2} p$ & $2 \sigma p$ & Criteria \\
\hline Plant Height $(\mathrm{cm})$ & 26.56 & 2659.65 & 166.76 & Broad & 2686.22 & 0.14 & Broad \\
\hline Number of Leaves & 0.52 & 138.75 & 7.97 & Broad & 139.28 & 0.02 & Broad \\
\hline Stem Diameter $(\mathrm{cm})$ & 0.07 & 4.99 & 0.34 & Broad & 5.06 & 0.01 & Broad \\
\hline Panicle Length $(\mathrm{cm})$ & 12.95 & 9206.55 & 515.25 & Broad & 9219.5 & 0.10 & Broad \\
\hline Number of Seeds per Panicle & 405537 & 125860168.2 & 7186137.17 & Broad & 126265705.06 & 17.83 & Broad \\
\hline Seed/Panicle Dry Weight (g) & 271.79 & 79463.18 & 4547.67 & Broad & 79735 & 0.46 & Broad \\
\hline Fresh Weight 1000 seeds (g) & 11.32 & 2847.39 & 164.05 & Broad & 2858.71 & 0.09 & Broad \\
\hline Dry Weight 1000 seeds (g) & 6.47 & 1213.8 & 71.15 & Broad & 1220.28 & 0.07 & Broad \\
\hline Leaf Length $(\mathrm{cm})$ & 29.47 & 13576.55 & 765.99 & Broad & 13606 & 0.15 & Broad \\
\hline Leaf Width $(\mathrm{cm})$ & 0.67 & 320 & 18.04 & Broad & 320.67 & 0.02 & Broad \\
\hline Plant Height at Harvest (cm) & 414.57 & 356701.73 & 19913.49 & Broad & 357116 & 0.57 & Broad \\
\hline Number of Tillers & 1.32 & 92.32 & 6.2 & Broad & 93.64 & 0.03 & Broad \\
\hline
\end{tabular}

Notes: $\boldsymbol{\sigma}^{2}$ e (Variety of Environment); $\boldsymbol{\sigma}^{2} \mathrm{~g}$ (Variety of Genotypes), $2 \boldsymbol{\sigma}$ g (Standard Deviation of Genotype Variety), Criteria for genotype variety: $\boldsymbol{\sigma}^{2} \mathrm{~g}<2 \boldsymbol{\sigma} \mathrm{g}$ (narrow) dan $\boldsymbol{\sigma}^{2} \mathrm{~g}>2 \boldsymbol{\sigma} \mathrm{g}$ (broad); $\boldsymbol{\sigma}^{2} \boldsymbol{p}$ (Variety of Phenotypes), $2 \boldsymbol{\sigma} \mathrm{p}$ (Standard Deviation of Phenotype Variety), Criteria for phenotype variety: $\boldsymbol{\sigma}^{2} \mathrm{p}<2 \boldsymbol{\sigma} \mathrm{p}$ (narrow) dan $\boldsymbol{\sigma}^{2} \mathrm{p}>2 \boldsymbol{\sigma} \mathrm{p}$ (broad).

Table 7. Heritability value and criteria of heritability in several east java local sorghum (Sorghum bicolor) genotypes

\begin{tabular}{lcc}
\hline \multicolumn{1}{c}{ Traits } & Heritability & Criteria \\
\hline Plant height $(\mathrm{cm})$ & 0.990 & High \\
Number of leaves & 0.996 & High \\
Stem diameter $(\mathrm{cm})$ & 0.986 & High \\
Panicle length $(\mathrm{cm})$ & 0.999 & High \\
Number of seeds per panicle & 0.997 & High \\
Seed/panicle dry weight $(\mathrm{g})$ & 0.997 & High \\
Fresh weight 1000 seeds $(\mathrm{g})$ & 0.996 & High \\
Dry weight 1000 seeds $(\mathrm{g})$ & 0.995 & High \\
Leaf length $(\mathrm{cm})$ & 0.998 & High \\
Leaf width $(\mathrm{cm})$ & 0.998 & High \\
Plant height at harvest $(\mathrm{cm})$ & 0.999 & High \\
Number of tillers & 0.986 & High \\
\hline
\end{tabular}

Description: High Heritability $(\mathrm{H} \geq 50 \%$ or $\mathrm{H} \geq 0.5$ Medium heritability $(20 \%<\mathrm{H}<50 \%$ or $0.2<\mathrm{H}<0.5)$, low Heritability $(\mathrm{H} \leq 20 \%$ or $\mathrm{H} \leq 0.2)$.

The high heritability followed by wide genetic diversity in the nine East Java local sorghum genotypes indicates that genetic factors influence the characters. The high heritability of some local East Java sorghum genotypes is due to genetic factors. If genetic factors play a more important role, these characters can be inherited, and it is hoped that selection can be useful for the observed traits (Maftuchah et al. 2015). Besides, Jimmy et al. (2017) reported that high heritability was generated by all observed agronomic characters and indicated that additive genes played a more critical role in improving plant breeding more quickly. This study's results are also in line with Setiawan et al. (2016), who showed that the plant height variables of 20 sorghum genotypes showed high heritability. The selection criteria for Sorghum could be used as a biomass producer. However, this research needs to study the local sorghum further as alternative food, animal feed, or industrial raw material.

In summary, the results showed that the SG-SPG 2 genotype produced the longest panicle size, while SGLMG 2 genotype produced the highest seed dry weight per panicle and the highest number of seeds per panicle
(117.34 grams of seed dry weight per panicle and 4581.80 seeds per panicle). The genotype of SG-TLG 2 produced the highest fresh weight (41.43 grams) and dry weight (31.96 grams) of 1000 seeds, but it was not different from SG-TLG 1. The highest number of tillers was produced by SG-TLG 2 (4.20 chicks) and was not significantly different from SG-TLG 1 (3.33 chicks) and SG-JBG (2.07 chicks). Of the nine genotypes tested, the flowering ages ranged from 42 to 53 days after planting, and the harvest ages ranged from 70 to 91 days after planting. The fastest harvest age was achieved by SG-TLG 2 (70 days after planting). All parameters tested showed the criteria for a wide range of genotypes and phenotypes. The entire value of the phenotype variety on each variable was more significant than the value of the genotype range. Heritability test results show that all experimental parameters exceed 0.5 so that it is categorized as high heritability. In general, the SG-TLG 2 genotype had the most chance to be developed, because it produced the highest seed weight, both fresh seeds (41.43 g/1000 seeds) and dry seeds (31.96 g/1000 seeds). Besides, the SG-TLG shows the fastest harvest age (70 days after planting).

\section{ACKNOWLEDGEMENTS}

The authors would like to thank the Directorate of Research and the Community Service University of Muhammadiyah Malang, Indonesia that has funded this research through the center of study's flagship program in 2017.

\section{REFERENCES}

Ardiyanti SE, Sopandie D, Wirnas D, Trikoesoemaningtyas. 2019. Ratoon productivity of sorghum breeding lines (Sorghum bicolor (L.) Moench). IOP Conf Ser Earth Environ Sci 399: 012030. DOI: 10.1088/1755-1315/399/1/012030.

Chaudhary RR. 2001. Genetic variability and heritability in sugarcane. Nepal Agric Res J 5. DOI: 10.3126/narj.v4i0.4870 
Elvira SD, Yusuf M, Maiyuslina. 2015. Karakter agronomi beberapa varietas sorgum pada lahan marginal di Aceh Utara. Jurnal Agrium 12 (1): 1-4. [Indonesian]

Falconer DS, Mackay TFC. 1996. Quantitative to Genetics. The Roland Press Company, New York.

Ferdian B, Sunyoto, Karyanto A, Kamal M. 2015. Akumulasi bahan kering beberapa varietas tanaman sorgum (Sorghum bicolor (L.) Moench) ratoon 1 pada kerapatan tanaman berbeda. Jurnal Agrotek Tropika 3 (1): 41-48. [Indonesian]

Jimmy ML, Nzuve F, Flourence O, Manyasa E, Muthomi J. 2017. Genetic variability, heritability, genetic advance and trait correlations in selected sorghum (Sorghum bicolor L. Moench) varieties. Intl J Agron Agric Res 11 (5): 47-56.

MoA. 2020. Data Produksi Padi dan Jagung 2014-2018. Kementerian Pertanian Indonesia, Jakarta httpswww.pertanian.go.idhomeshow=page \&act=view\&id=61. [Indonesian]

Kotal BD, Das A, Choudhury BK. 2010. Genetic variability and association of characters in wheat (Triticum aestivum L.). Asian J Crop Sci 2 (3): 155-160. DOI: 10.3923/ajcs.2010.155.160.

Kusumawati A, Putri NK, Suliansyah I. 2013. Karakterisasi dan evaluasi beberapa genotipe sorgum (Sorghum bicolor L ) di Sukarami Kabupaten Solok. Jurnal Agroteknologi 4 (1): 7-12. DOI: 10.24014/ja.v4i1.57. [Indonesian]

Mac Whirter KS. 1979. Breeding of cross pollinated crops. In: Knight R (ed.) Plant Breeding. Australian Vice-Chancellors' Committee, Brisbane, Australia.

Maftuchah, Reswari HA, Ishartati E, Zainudin A, Sudarmo H. 2015 Heritability and correlation of vegetative and generative character on genotypes of jatropha (Jatropha curcas Linn.). Energy Procedia 65: 186-193. DOI: 10.1016/j.egypro.2015.01.058.

Mundia CW, Secchi S, Akamani K, Wang G. 2019. A Regional comparison of factor affecting global sorghum production: The case of North America, Asia and Africa's sahel. Sustainability 11: 2135. DOI: $10.3390 /$ su 11072135 .

Panjaitan R, Zuhry E, Deviona. 2015. Karakterisasi dan hubungan kekerabatan 13 genotipe sorgum (Sorghum bicolor L.) Mouch koleksi Batan. Jurnal JOM Faperta 2 (1). [Indonesian]

Pinaria A, Baihaki A, Setiamihardja A, Daradjat AA. 1995. Penampilan fenotipik dan beberapa parameter genetik delapan kultivar kacang tanah pada lahan sawah. Zuriat 11 (1): 8-15. [Indonesian]
Rahajeng W, Rahayuningtyas A. 2015. Pendugaan komponen ragam, heritabilitas dan korelasi klon-klon harapan ubijalar berkadar betakaroten tinggi. Jurnal Ilmu Pertanian 18 (1). DOI: 10.22146/ipas.6177. [Indonesian]

Rifa'i H, Ashari S, Damanhuri. 2015. Keragaman 36 aksesi sorgum (Sorghum bicolor L.). Jurnal Produksi Tanaman 3 (4): 330-337. [Indonesian]

Seetharam K, Ganesamurthy K. 2013. Characterization of sorghum genotypes for yield and other agronomic traits through genetic variability and diversity analysis. Electr J Plant Breed 4 (1): 1073 1079.

Setiawan K, Kamal M, Hadi MS, Sungkono, Maulana I. 2016. Keragaan beberapa kandidat genotip sorgum sebagai penghasil biomasa. Prosiding Seminar Nasional dan Kongres 2016 Perhimpunan Agronomi Indonesia (PERAGI). Departemen Agronomi dan Hortikultura, Institut Pertanian Bogor, Bogor. [Indonesian]

Setiawan K, Restiningtias R, Utomo SD, Ardian, Hadi MS, Yuliadi E. 2019. Keragaman genetik, fenotip, dan heritabilitas beberapa genotipe sorghum pada kondisi tumpangsari dan monokultur. Jurnal Agro 6 (2): 95-109. DOI: 10.15575/4568. [Indonesian]

Setiyagama MJ, Arifin AZ, Sulistyawati. 2017. Karakterisasi beberapa genotip sorgum (Sorghum bicolor L.) lokal Jawa Timur. Jurnal Agroteknologi Merdeka Pasuruan 1 (2): 18-22. [Indonesian]

Sirappa MP, Waas ED. 2009. Kajian varietas dan pemupukan terhadap peningkatan hasil padi sawah di Dataran Pasahari, Maluku Tengah. Jurnal Pengkajian dan Pengembangan Teknologi Pertanian 12 (1). [Indonesian]

Sulistyawati, Roeswitawati D, Ibrahim JT, Maftuchah. 2019a. Agronomic character of several local genotypes of sorghum (Sorghum bicolor L.) at East Java. IOP Conf Series: Materials Science and Engineering 532. DOI: $10.1088 / 1757-899 X / 532 / 1 / 012023$

Sulistyawati, Roeswitawati D, Ibrahim JT, Maftuchah. 2019b. Genetic diversity of local sorghum (Sorghum bicolor) genotypes of East Java, Indonesia for agro-morphological and physiological traits. Biodiversitas 20 (9): 2503-2510. DOI: 10.13057/biodiv/d200911

Susilowati SH, Saliem HP. 2013. Perdagangan Sorgum di Pasar Dunia dan Asia serta Prospek Pengembangannya di Indonesia. Dalam: Sumarno, Damardjati DS, Syam D, Hermanto (eds). Sorgum: Inovasi Teknologi dan Pengembangan. IAARD Press, Jakarta. [Indonesian] 